\title{
PENGARUH KUALIFIKASI GURU TERHADAP PENINGKATAN MUTU GURU AGAMA DI SEKOLAH DAN MADRASAH
}

\author{
Hayadin \\ Puslitbang Lektur dan Naskah Keagamaan | Balitbang dan Diklat Kemenag RI \\ Jl. MH Thamrin No.06 Jakarta Pusat | hayadin006@gmail.com
}

\begin{abstract}
This study aimed to determine the effect on the quality of teacher qualifications towards teachers qualities in the school and religious education in madrasas. These were include teachers' pedagogical knowledge, the ability to make a lesson plan, the increasing of student test scores, and the teachers performance and creativity. This study was undertaken toward madrasas' teacher qualification improvement programs followers and religious education teacher at the school as well, through graduate school scholarship program. The data collecting techniques was using survey. The samples consisted of madrassa teacher and teacher of religion in the public schools of alumni scholarships $S 2$ and S1. The research instrument consisted of a questionnaire, and documents. The results showed that teacher qualification have had influence on teachers' pedagogical knowledge, the ability to create lesson plans, performance and teacher creativity and innovation.
\end{abstract}

Keywords: teacher qualifications, quality of teachers, alumni of graduate schools, creativity teacher, student learning outcomes.

\section{Abstrak}

Penelitian ini bertujuan untuk mengetahui pengaruh kualifikasi guru terhadap mutu guru agama di sekolah dan di madrasah. Hal tersebut meliputi pengetahuan pedagogik guru, kemampuan merencanakan pelajaran, peningkatan nilai ujian siswa, kinerja dan kreativitas guru. Penelitian ini dilakukan terkait dengan program peningkatan kualifikasi guru madrasah dan guru pendidikan agama di sekolah melalui program beasiswa strata dua. Pengumpulan data menggunakan teknik survei. Sampel penelitian adalah guru madrasah dan guru agama pada sekolah umum alumni beasiswa S2 dan S1. Instrumen penelitian terdiri atas angket, dan dokumen. Hasil penelitian menunjukan bahwa kualifikasi guru memberikan pengaruh terhadap pengetahuan pedagogik guru, kemampuan membuat perencanaan pembelajaran, kinerja dan kreativitas serta inovasi guru.

Kata kunci: kualifikasi guru, mutu guru, alumni strata dua, kreativitas guru, hasil belajar siswa.

\section{PENDAHULUAN}

Tuntutan terhadap pendidikan yang bermutu semakin gencar disuarakan oleh banyak pihak di tanah air seiring dengan tuntutan pemerataan kesempatan memperoleh pendidikan bagi anak usia wajib sekolah. Kedua tuntutan tersebut, berkembang kearah tuntutan terhadap pemerataan kesempatan memperoleh pendidikan yang bermutu.
Sehingga bagi pemerintah dan pihak-pihak lainnya yang menyelenggarakan pendidikan menjadi wajib hukumnya memenuhi standard mutu tertentu kepada pelanggannya. Dalam konteks masyarakat atau orang tua siswa, pendidikan yang bermutu menjadi hak yang harus diperoleh atas kewajiban mereka membayar biaya kontribusi pendidikan dan pajak. Sementara bagi pemerintah dan 
penyelenggara pendidikan lainnya, layanan pendidikan yang bermutu menjadi kewajiban yang harus ditunaikan.

Dalam konteks tataranglobal, pembicaraan tentang mutu pendidikan dan pendidik tidak hanya menjadi aktual karena menjadi prasyarat untuk berkompetisi dengan negara lain di pentas internasional, tetapi telah menjadi kesepakatan dalam rangka membangun tatanan dunia baru yang lebih maju. Disadari secara internasional bahwa ketimpangan mutu pendidikan antar negara akan melahirkan ketimpangan pula dalam hubungan ekonomi dan perdagangan internasional. Oleh karena itu, berbagai standarn mutu yang bersifat internasional telah dikembangkan sebagai acuan setiap bangsa dan negara dalam mengejar target mutu pendidikannya masingmasing.

Melalui standar dan kriteria yang ditetapkan dalam setiap pengukuran mutu pendidikan antar bangsa, setiap negara kemudian dapat melihat posisinya di antara bangsa-bangsa lain, serta dengan mudah memahami kekurangan dan kelemahan yang masih dimiliki. Posisi negara Indonesia dalam standard tersebut terbilang masih rendah dan memerlukan strategi, dan usaha yang maksimal.

Dalam laporan UNDP tahun 2013, posisi HDI (human development index) berada pada ranking 121, berada di bawah peringkat Thailand (103) dan Philipina (ranking114), Malaysia (ranking 64), dan Singapore (18) ${ }^{1}$. UNICEF dalam laporan Education for All Global Monitoring Report EDI tahun 2011 Indonesia berada pada peringkat ke-69 dari 127 negara di dunia. ${ }^{2}$ Peringkat tersebut menunjukkan bahwa mutu pendidikan Indonesia berada pada tingkat sedang (dari tiga kategori yang ada, yakni: bermutu tinggi, sedang, dan rendah).

${ }^{1}$ Anonim, Human Develoment Report, 6 Oktober 2013: http://hdr.undp.org/en/statistics/

${ }^{2}$ Muhamad Azhar, Kualitas Pendidikan Indonesia Ranking 69 tingkat Dunia: http://azharmind.blogspot. com/2012/02/kualitas-pendidikan-indonesia-ranking. html
Dalam laporan tersebut, dinyatakan bahwa negara dengan sistem pendidikan terbaik di dunia adalah Finlandia. Salah satu keunggulan negera Finlandia di bidang pendidikan adalah guru yang mendidik anak di sekolah. Di Finlandia, guru berasal dari sepuluh lulusan terbaik (The Best Tens) dan berkualifikasi strata 2 .

Dalam upaya meningkatkan kualitas guru, Kementerian Agama RI sejak beberapa tahun yang lampau telah menyelenggarakan program pengembangan kualitas guru melalui jalur pendidikan, yakni peningkatan kualifikasi guru pada Strata 2. Program tersebut bertujuan untuk meningkatkan kompetensi, pengetahuan, kreativitas, dan inovasi guru madrasah dan pendidikan agama dalam mengajar. Diharapkan melalui program trersebut, kualitas pengajaran agama di Sekolah dan di Madrasah menjadi lebih baik. Untuk itu, maka penelitian ini berupaya untuk menjelaskan pengaruh peningkatan kualifikasi tersebut terhadap mutu guru.

Secara detail rumusan permasalahan penelitian (research problem statements) dinyatakan sebagai berikut: a). Apakah terdapat pengaruh peningkatan kualifikasi guru terhadap peningkatan pengetahuan pedagogik guru? b). Apakah terdapat pengaruh peningkatan kualifikasi guru terhadap kemampuan merencanakan pelajaran? c). Apakah terdapat pengaruh peningkatan kualifikasi guru terhadap kinerja guru yang dipersepsi oleh kepala sekolah? d). Apakah terdapat pengaruh peningkatan kualifikasi guru terhadap kinerja yang di persepsi oleh siswa? e). Apakah terdapat pengaruh peningkatan kualifikasi guru terhadap kreativitas, dan Inovasi guru?

Tujuan penelitian (goal research statements) adalah untuk mengetahui: a). Pengaruh peningkatan kualifikasi guru terhadap peningkatan Pengetahuan Pedagogik guru; b). Pengaruh peningkatan kualifikasi guru terhadap Kemampuan Merencanakan Pelajaran; c). Pengaruh peningkatan kualifikasi guru terhadap kinerja guru yang dipersepsi oleh Kepala Sekolah; d). Pengaruh peningkatan 
kualifikasi guru terhadap Kinerja yang di persepsi oleh siswa; e). Pengaruh peningkatan kualifikasi guru terhadap Kreativitas, dan Inovasi Guru.

Dengan tujuan tersebut, penelitian ini diharapkan membawa manfaat untuk memperkaya landasan konseptual bagi perbaikan model peningkatan kualifikasi dan kompetensi guru, khususnya guru pendidikan agama Islam (GPAI) di Indonesia. Pada tataran kebijakan, penelitian ini akan menjadi landasan akademis bagi penyelenggaraan program peningkatan mutu pendidik dan pendidikan baik di madrasah maupun peningkatan mutu pendidikan agama di sekolah dan guru secara umum di Indonesia.

Penelitian menggunakan metode survei, dilakukan pada tahun 2013 di wilayah: Jawa barat, Jawa tengah, Daerah Istimewa Yogyakarta, Jawa timur, Banten, Nusa tenggara barat, Sulawesi selatan, Lampung, Sumatera utara, dan Pekan baru. Berdasarkan data sampelnya, penelitian ini berbentuk kuasi eksperiment, hal ini merujuk pada data sample alumni strata 2 yang sudah terlebih dahulu ada melalui program pemerintah.

Populasi penelitian adalah guru yang telah menyelesaikan program beasiswa Strata 2 peningkatan kualifikasi guru, dan guru yang belum memperoleh kesempatan untuk mengikuti strata 2 . Teknik pemilihan sampel (sampling) dilakukan secara acak (random). Pada tahap awal, mempertimbangkan daerah (Provinsi) dengan jumlah alumni beasiswa strata 2 terbanyak. Tahap selanjutnya adalah memilih daerah kabupatan/kota dengan jumlah alumni beasiswa strata 2 terbanyak. Dan selanjutnya menentukan sekolah dengan jumlah alumni beasiswa strata 2 terbanyak pula. Jumlah sampel setiap kabupaten/kota adalah 10 orang. Selanjutnya pada daerah kabupaten, kota, sekolah dan madrasah yang menjadi sasaran sampel, dipilih pula guru strata 1 sebagai pembanding (counter-comparatives) dengan jumlah yang sama. Pemilihan guru sebagai pembanding tersebut dilakukan secara acak (random) berdasarkan data yang tersedia di kantor kementerian agama kabupaten/kota, atau sekolah, dengan mempertimbangkan kriteria kompetensi mengajar yang unggul. Sehingga jumlah sampel pada setiap kabupaten/kota berumlah sebanyak 20 orang, yakni: 10 orang alumni beasiswa strata 2 dan 10 orang sisanya adalah guru strata 1 yang belum berkesempatan menempuh kuliah strata 2 .

Instrumen dan teknik untuk pengumpulan data adalah angket, test, studi dokumentasi. Sumber data berasal dari: guru yang berstatus sebagai sampel dengan mengisi test pengetahuan pedagogik, kepala sekolah dan siswa dengan mengisi angket penilaian, dan dokumen yakni rencana program pembelajaran yang dibuat oleh guru. Data yang terkumpul, diolah dan dianalisis secara kuantitatif dalam bentuk deskriptif statistik dan inferensial. Alat menganalisis data menggunakan soft-ware SPSS-18 (PSW-18). ANACOVA. Hipotesis penelitian dirumuskan sebagai berikut: a). Hipotesis pertama: Tidak terdapat pengaruh peningkatan kualifikasi guru terhadap peningkatan Pengetahuan Pedagogik guru (Ho), dengan alternatif: terdapat pengaruh peningkatan kualifikasi guru terhadap peningkatan Pengetahuan Pedagogik guru (H1). b). Hipotesis kedua:Tidak terdapat pengaruh peningkatan kualifikasi guru terhadap Kemampuan Merencanakan Pelajaran (Ho), dengan alternatif: Terdapat pengaruh peningkatan kualifikasi guru terhadap Kemampuan Merencanakan Pelajaran (H1). c). Hipotesis ketiga: Tidak terdapat pengaruh peningkatan kualifikasi guru terhadap Kinerja Guru yang dipersepsi oleh Kepala Sekolah (Ho), dengan alternatif: Terdapat pengaruh peningkatan kualifikasi guru terhadap Kinerja Guru yang dipersepsi oleh Kepala Sekolah (H1). d). Hipotesis keempat: Tidak terdapat pengaruh peningkatan kualifikasi guru terhadap Kinerja yang di persepsi oleh siswa (HO), dengan alternatif: terdapat pengaruh peningkatan kualifikasi guru terhadap Kinerja yang di persepsi oleh siswa (H1). 


\section{Kerangka Konseptual}

\section{Kualifikasi Guru}

Dalam businessdictionary.com disebutkan bahwa qualification is capacity, knowledge, or skill that matches or suits an occasion, or makes someone eligible for a duty, office, position, privilege, or status. ${ }^{3}$ Kualifikasi dapat diartikan sebagai kapasitas, pengetahuan atau keterampilan yang dimiliki seseorang sehingga orang tersebut memenuhi syarat untuk mendapatkan sebuah tugas/posisi/tanggungjawab. Hal senada juga dimuat dalam thefreedictionary. com bahwa qualificatioan is a quality, ability, or accomplishment that makes a person suitable for a particular position or task. ${ }^{4}$

Bila definisi tersebut di atas dikaitkan dengan kualifikasi guru, maka dapat dinyatakan bahwa kualifikasi guru adalah kapasitas, pengetahuan dan atau keterampilan yang harus dimiliki oleh seorang guru sehingga mampu atau memenuhi syarat untuk mengemban tugas dan tanggungjawab sebagai guru. Mengenai kualifikasi guru ini, dalam en.wikipedia.org dinyatakan bahwa a teaching qualification or teacher qualification is one of a number of academic and professional degrees that enables a person to become a registered teacher in primary or secondary school. ${ }^{5}$

Secara terminologis, kualifikasi guru merujuk pada jenjang akademik yang berhasil diselesaikan oleh seorang guru yang menjadi syarat baginya untuk melakukan tugas profesionalnya. Pendidik harus memiliki kualifikasi akademik dan kompetensi sebagai agen pembelajaran, sehat jasmani dan rohani, serta memiliki kemampuan untuk mewujudkan tujuan pendidikan nasional. ${ }^{6}$ Sebagaimana dimaksud pada PP. No. 19 Tahun 2005 tentang SNP, pasal 28 ayat (1) maka yang dimaksud dengan kualifikasi akademik adalah tingkat

3 http://www.businessdictionary.com/definition/ qualification.html.

${ }^{4} \mathrm{http}: / /$ www.thefreedictionary.com/qualification.

${ }^{5} \mathrm{http}$ ///en.wikipedia.org/wiki/Teaching_qualification.

${ }^{6}$ PP. No. 19 tahun 2005, tentang SNP, pasal 28; 1. pendidikan minimal yang harus dipenuhi oleh seorang pendidik yang dibuktikan dengan ijazah dan/atau sertifikat keahlian yang relevan sesuai ketentuan perundangundangan yang berlaku. ${ }^{7}$ Peningkatan kualitas guru tersebut dapat diperoleh melalui beberapa cara, misalnya dengan pelatihan, penataran, dan peningkatan kualifikasi pendidikan guru. Peningkatan kualifikasi guru secara akademik sangat penting dilakukan untuk memperbaharui dan mengembangkan ilmu pengetahuan yang dimiliki oleh guru.

Pemenuhan kualifikasi guru ini sangat penting mengingat peran guru baik dalam pendidikan secara umum maupun dalam pembelajaran secara khusus. Guru merupakan elemen kunci dalam sistem pendidikan, khususnya di sekolah. Semua komponen lain, mulai dari kurikulum, sarana-prasarana, biaya, dan sebagainya tidak banyak berarti apabila esensi/inti pembelajaran yaitu interaksi guru dengan peserta didik tidak berkualitas. Untuk menciptakan interaksi yang berkualitas, salah satu hal penting yang harus dipenuhi adalah adanya guru yang memenuhi kualifikasi yang dipersyaratkan. Bila guru telah memenuhi kualifikasi yang dipersyaratkan kemudian meng-upgrade lagi kualifikasi yang dimilikinya, maka diharapkan akan ikut meng-upgrade kualitas pembelajaran yang dilaksanakannya.

Pandangan para pakar tentang mutu sangat beragam. Juran mendefinisikan mutu sebagai fitness for use, kesesuaian untuk penggunaan produk, ini berarti bahwa suatu produk atau jasa hendaklah sesuai dengan apa yang diperlukan atau diharapkan oleh pengguna. ${ }^{8}$ Sedangkan menurut Deming, mutu ialah continuous improvement. ${ }^{9}$ De Toro dalam M. Ali menyatakan bahwa "quality is a basic bussines strategy that provides goods and services that completely satisfy both internal and external

${ }^{7}$ PP. No. 19 tahun 2005, tentang SNP, pasal 28; 2 .

${ }^{8}$ J.M. Juran. 1989. Juran on Leadership for Quality, An Executive Handbook. New York: Macmillan Inc. p. 15.

${ }^{9}$ Kerzner Harold. 2009. Project Management: A System Approach To Planning, Schedulling And Controlling. New Jersey: Jhon Willey\& Sons, Inc Hoboken. p. 881. 
customers by meeting their explicit expectation. ${ }^{10}$ Dalam pengertian ini, mutu diartikan sebagai hal yang memuaskan pelanggan baik pelanggan internal maupun eksternal dengan mencocokkan sesuai dengan yang diharapkan oleh pelanggan tersebut.

Sallis menyatakan konsep mutu ada yang bersifat absolut dan relatif. Dalam konsep absolut sesuatu (barang) disebut berkualitas bila memenuhi standar tertinggi dan sempurna. Artinya, barang tersebut sudah tidak ada yang melebihi. Sedangkan, dalam konsep relatif, kualitas berarti memenuhi spesifikasi yang ditetapkan dan sesuai dengan tujuan (fit for their purpose). Edward Sallis mengemukakan kualitas dalam konsep relatif berhubungan dengan produsen, maka mutu berarti sesuai dengan spesifikasi yang ditetapkan pelanggan. ${ }^{11}$ Crosby mendefinisikan mutu sebagai conformance to requirement atau kesesuaian dengan yang disyaratkan. ${ }^{12}$

Beragamnya pandangan tentang mutu tersebut tidak saja berdampak di bidang ekonomi dan bisnis tetapi juga dalam bidang pendidikan. Defenisi mutu pendidikan merupakan sesuatu yang sangat kompleks dan sulit dirumuskan, karena sifatnya yang eklektik yaitu dapat dilihat dari berbagai sudut pandang dan kepentingan. Perbedaan sudut pandang dan kepentingan tersebut didasarkan pada pendapat bahwa, paling tidak ada tiga pihak yang berkepentingan dalam pendidikan, yaitu pihak yang mengatur pendidikan, pihak yang melaksanakan pendidikan, dan pihak yang memperoleh manfaat pendidikan secara langsung maupun tidak langsung.

Charles Hoy dkk, merumuskan bahwa yang dimaksud dengan mutu pendidikan adalah suatu evaluasi atas proses mendidik

${ }^{10}$ M.Ali. 2009. Pendidikan Untuk Pembangunan Nasional. Bandung: Imperial Bhakti Utama. p.335.

11 Edward Sallis. 2008. Total Quality Management in Education: Manajemen Mutu Pendidikan. Yogyakarta: IRCiSod. p. 53.

${ }^{12}$ Kerzner Harold.2009. Project Management: A System Approach to Planning, Schedulling and Controlling. New Jersey: Jhon Willey \& Sons,Inc Hoboken. p. 882. yang dapat meningkatkan kebutuhan untuk mengembangkan dan membina bakat peserta didik, proses pendidikan itu sendiri; dan bersamaan dengan itu, memenuhi standar akuntabilitas yang ditetapkan oleh mereka yang bertanggungjawab membiayai dan menerima lulusan pendidikan. ${ }^{13}$

Mutu di bidang pendidikan meliputi mutu input, proses, output, dan outcome. Input pendidikan dinyatakan bermutu jika siap berproses. Proses pendidikan bermutu apabila mampu menciptakan suasana pembelajaran yang aktif, kreatif, dan menyenangkan. Output dinyatakan bermutu apabila hasil belajar akademik dan nonakademik peserta didik tinggi. Outcome dinyatakan bermutu apabila lulusan cepat terserap di dunia kerja, gaji wajar, semua pihak mengakui kehebatannya lulusannya dan merasa puas. ${ }^{14}$

Danim menyatakan bahwa mutu pendidikan mengacu pada masukan, proses, luaran dan dampaknya. Mutu masukan dapat di lihat dari beberapa sisi. Pertama, kondisi baik atau tidaknya masukan sumber daya manusia, seperti kepala sekolah, guru, laboran, staf tata usaha, dan siswa. Kedua, memenuhi atau tidaknya criteria masukan material berupa alat peraga, buku-buku, kurikulum, prasarana, sarana sekolah, dan lain-lain. Ketiga, memenuhi atau tidaknya criteria masukan yang berupa perangkat lunak, seperti peraturan, struktur organisasi, deskripsi kerja, dan struktur organisasi. Keempat, mutu masukan yang bersifat harapan dan kebutuhan, seperti visi, motivasi, ketekunan, dan cita-cita. Mutu proses pembelajaran mengandung makna bahwa kemampuan sumber daya sekolah menmtransformasikan multi jenis masukan dan situasi untuk mencapai derjat nilai tambah tertentu dari peserta didik. Dilihat dari hasil pendidikan, guru dipandang berkualitas jika

${ }^{13}$ Charles Hoy, Colin Bayne-Jardin, dan Margaret Wood. 200. Improving Quality in Education. London: Falmer Press. h. 10.

${ }^{14}$ Usman, Husaini. 2006. Manajemen Teori, Praktek Dan Riset Pendidikan, Jakarta: Bumi Aksara. p. 410. 
mampu melahirkan keunggulan akademis dan ekstrakurikuler pada peserta didik yang dinyatakan lulus untuk satujenjang pendidikan atau menyelesaikan program pembelajaran tertentu. ${ }^{15}$

Hari Sudradjad pendidikan yang bermutu adalah pendidikan yang mampu menghasilkan lulusan yang memiliki kemampuan atau kompotensi, baik kompetensi akademik maupun kompetensi kejuruan, yang dilandasi oleh kompetensi personal dan sosial, serta nilai-nilai akhlak mulia, yang keseluruhannya merupakan kecakapan hidup (life skill). Lebih lanjut Sudradjat mengemukakan pendidikan bermutu adalah pendidikan yang mampu menghasilkan manusia seutuhnya (manusia paripurna) atau manusia dengan pribadi yang integral (integrated personality) yaitu mereka yang mampu mengintegralkan iman, ilmu, dan amal. ${ }^{16}$

Pendidikan sebagai usaha jasa, kualitasnya dapat diketahui dengan cara membandingkan persepsi pelanggan atas pelayanan yang diperoleh atau diterima secara nyata oleh mereka dengan pelayanan yang sesungguhnya diharapkan. Jika kenyataan lebih dari yang diharapkan, pelayanan dapat dikatakan bermutu. Sebaliknya, jika kenyataan kurang dari yang diharapkan, pelayanan dapat dikatakan tidak bermutu. Namun, apabila kenyataan sama dengan harapan, maka kualitas pelayanan disebut memuaskan. Dengan demikian, kualitas pelayanan dapat didefenisikan seberapa jauh perbedanaan antara kenyataan dan harapan para pelanggan atas layanan yang diterima mereka. ${ }^{17}$

Jika dirujuk pada standard nasional pendidikan, maka aspek yang terkandung

${ }^{15}$ Sudarwan Danim. 2008. Visi Baru Manajemen Sekolah; Dari Unit Birokrasi ke Lembaga Akademik. Jakarta: Bumi Aksara. p.53.

${ }^{16}$ Suderadjat, Hari. 2005. Manajemen Peningkatan Mutu Berbasis Sekolah; Peningkatan Mutu Pendidikan Melalui Implementasi KBK, Bandung: Cipta Lekas Garafika. p.17.

${ }_{17}$ Umiarso \& Imam Gojali. 2010. Manajemen Mutu Sekolah di Era Otonomi Pendidikan. Jogjakarta: IRCiSoD. p. 126. dalam sebuah sistem pendidikan yang bermutu adalah: input, proses dan output. Variabel input dalam sistem pendidikan meliputi: isi dan sasaran kompetensi pembelajaran, proses pembelajaran, sistem evaluasi, tenaga pendidik, sarana-prasarana, standar pembiayaan, sistem manajemen. Variabel proses dalam sistem pendidikan meliputi: standar proses pembelajaran dan standar pengelolaan. Variabel output dalam sistem pendidikan meliputi prestasi dan hasil belajar peserta didik. Dalam konstelasi sistem mutu input, proses, dan output pada satuan pendidikan, maka secara spesifik mutu dapat ditelaah dari 2 segi yaitu mutu peserta didik dan mutu guru. Dalam hal ini berbagai macam faktor yang terkait dengan mutu peserta didik dan mutu guru akan turut menentukan atau akan berdampak terhadap mutu output pendidikan secara keseluruhan.

\section{Mutu Guru}

Guru adalah pendidik profesional dengan tugas utama mendidik, mengajar, membimbing, mengarahkan, melatih, menilai, dan mengevaluasi peserta didik pada pendidikan anak usia dini jalur pendidikan formal, pendidikan dasar, dan pendidikan menengah. ${ }^{18}$

Menurut Djamarah, guru adalah orang yang memberikan ilmu pengetahuan kepada anak didik. ${ }^{19}$ Pada pendapat ini, semua orang yang memberikan ilmu pengetahuan kepada anak didik dapat dikatakan sebagai guru. Guru memiliki tanggung jawab untuk mendidik peserta didik agar mereka siap menghadapi tantangan-tantangan dalam kehidupannya.

Berdasarkan Peraturan Menteri Pendidikan Nasional Republik Indonesia Nomor 16 Tahun 2007 tentang Standar Kualifikasi Akademik dan Kompetensi Guru dijelaskan bahwa Standar Kompetensi Guru

${ }^{18}$ Pasal 1 ayat 1 UU RI No. 14 Tahun 2005 tentang Guru dan Dosen.

${ }^{19}$ Syaiful Bahri Djamarah. 200. Guru dan Anak Didik dalam Interaksi Edukatif. Jakarta: PT Rineka Cipta. h. 31. 
dikembangkan secara utuh dari 4 kompetensi utama, yaitu: (1) kompetensi pedagogik, (2) kepribadian, (3) sosial, dan (4) profesional. Keempat kompetensi tersebut terintegrasi dalam kinerja guru. Walaupun demikian, kompetensi pedagogik guru merupakan poin penting yang menunjang kinerja guru dalam berinteraksi dengan peserta didik.

Kompetensi pedagogik ini berkaitan dengan kemampuan mengajar guru di kelas. Adapun yang dimaksud dengan kompetensi paedagogik adalah kemampuan mengelola pembelajaran peserta didik. ${ }^{20}$ Kompetensi ini berhubungan dengan keterampilan guru dalam melaksanakan proses pembelajaran di kelas.

Guru yang profesional dan berkualitas mampu melaksanakan tanggungjawab yang dibebankan kepadanya. Achmad Badawi mengatakan bahwa "guru dikatakan berkualitas apabila seorang guru dapat menampilkan kelakuan yang baik dalam usaha mengajarnya." ${ }^{21}$ Dalam upaya menampilkan pembelajaran yang berkualitas, maka guru memiliki tanggungjawab untuk merencanakan, melaksanakan dan mengevaluasi pendidikan.

Berdasarkan pada uraian di atas, terlihat bahwa guru yang bermutu adalah guru yang mampu menampilkan kinerja/performa yang baik dalam mengajar. Performa yang baik ini lahir dari perencanaan yang baik, pelaksanaan yang baik, dan tentu saja evaluasi yang baik pula. Hal inilah yang menjadi output dari seorang guru yang bermutu. Selanjutnya outcome yang diharapkan dari seorang guru yang berkualitas misalnya penelitian tindakan kelas dan riset pembelajaran lainnya, penulisan buku, jurnal (karya ilmiah) dan artikel. Dengan demikian, secara keseluruhan diharapkan guru yang bermutu ini akan mampu meningkatkan mutu pendidikan secara umum.

${ }^{20}$ Penjelasan Pasal 10 ayat 1 UU RI No. 14 Tahun 2005 tentang Guru dan Dosen.

${ }^{21}$ B. Suryosubroto. 2002. Proses Belajar Mengajar di Sekolah, Jakarta: PT Rineka Cipta. h. 20.

\section{Hasil Penelitian yang Relevan}

Laporan Kajian Staf Ahli Mendiknas Bidang mutu pendidikan Departemen Pendidikan Nasional pada tahun 2006 tentang Prakarsa Sekolah dalam Meningkatkan Mutu Proses Pendidikan menyebutkan bahwa latar belakang pendidikan dan pengalaman guru menentukan kreativitas guru dalam mengembangkan proses pembelajaran. ${ }^{22}$ Hasil pengkajian ini sangat jelas menyebutkan latar belakang pendidikan sebagai salah satu faktor yang menentukan kreativitas guru dalam mengembangkan proses pembelajaran. Kreativitas guru yang baik dalam proses pembelajaran akan menjadikan pembelajaran lebih bermakna dan berkualitas, sebaliknya kreativitas guru yang minim/rendah cenderung menjadikan pembelajaran sebagai sesuatu yang monoton dan membosankan bagi peserta didik.

Penelitian Lembaga Penilaian Pendidikan Jakarta (LPPJ) pada tahun 2009, tentang "Evaluasi Program Beasiswa Guru dan Karyawan Departemen Agama tahun 2006". Penelitian ini dengan menggunakan metode evaluasi CIPPO (contex, input, proses, product, dan outcome) telah melaporkan banyak hal tentang pelaksanaan program beasiswa studi strata 2 , antara lain: konteks penyelenggaraan program telah sesuai dengan tujuan yang diinginkan oleh pemerintah yakni meningkatkan kualifikasi dan kompetensi guru bidang studi; meningkatkan rasa percaya diri, dan kapabilitas; serta meningkatkan kesejahteraan guru. Para alumni beasiswa strata 2 juga memiliki rasa percaya diri dan kapabilitas yang lebih baik, mereka banyak yang menjadi inisiator danleading person para organisasi MGMP. Mereka juga banyak diminta untuk mengajar pada madrasah swasta serta mengisi kegiatan sosial-keagamaan di tempat ibadah. Dampaknya setelah kembali ke seekolah dan masyarakat, mereka memiliki kompetensi lebih, seperti: kecakapan mengoperasikan

${ }^{22}$ Harina Yuhetty, dkk. 2006. Laporan Kajian 'Prakarsa Sekolah dalam Meningkatkan Mutu Proses Pendidikan (Studi Kasus pada SMA/MA Terpilih)'. Jakarta: Depdiknas. h. 78. 
perangkat komputer dan internet, menulis modul, buku pelajaran dan kegiatan sekolah lain yang bersifat kreatif dan inovatif.

Penelitian lainnya yang relevan adalah "Penelitian Kompetensi Guru Honorer di Jawa Tengah" oleh Puslitbang PENDA tahun 2011. Penelitian ini menyimpulkan antara lain: pengetahuan pedagogik guru rekruitment tenaga honorer termasuk dalam kategori kurang; kemampuanmembuat perencanaan pembelajaran termasuk dalam kategori cukup; kemampuan melakukan pembelajaran termasuk dalam kategori cukup.

\section{Definisi, Ruang lingkup dan Kerangka Berpikir}

Secara konseptual kualifikasi adalah seperangkat keahlian, pengetahuan dan keterampilan yang dibutuhkan untuk menyelesaikan suatu tugas, posisi, atau tanggung jawab tertentu. Mutu guru adalah kondisi yang menggambarkan kecakapan dan kemampuan pedagogik guru, keterampilan membuat perencanaan pelajaran, dan kecakapan memenuhi penilaian pimpinan dan siswa dalam proses pembelajaran di sekolah. Ruang lingkup penelitian meliputi: tes kompetensi pedagogik guru, penilaian portopolio perencanaan mengajar, penilaian kinerja guru pendidikan agama oleh kepala sekolah dan kepala madrasah serta siswa, serta kreativitas dan inovasi guru.

Dari ruang lingkup tersebut, dapat ditarik pengertian bahwa guru yang telah menyelesaikan qualifikasi pendidikan strata 2, akan memiliki kompetensi pedagogik yang tinggi, kemampuan membuat perencanaan pembelajaran yang baik, memperlihatkan kinerja yang unggul, baik dimata kepala sekolah/madrasah, ataupun dimata siswa, serta memiliki kreativitas dan inovatif dalam mengajar.

\section{HASIL DAN PEMBAHASAN}

\section{Kompetensi Pedagogik Guru}

Salah satu instrumen yang digunakan untuk menilai mutu guru dalam penelitian ini adalah tes Pedagogik guru. Test terdiri atas 80 item yang menanyakan pengetahuan umum tentang konsep pengajaran atau pedagogik secara umum. Berdasarkan hasil pengolahan data, diperoleh skor deskriptif sebagai berikut:

Tabel-1:

Hasil Tes Pedagogik antara guru alumni S1 dan alumni S2.

\begin{tabular}{|l|l|l|l|}
\hline No & Deskripsi & Nilai Guru S1 & Nilai Guru S2 \\
\hline 1. & Jumlah & 5813 & 6950 \\
\hline 2. & Skor tertinggi & $\mathbf{6 1}$ & $\mathbf{6 1}$ \\
\hline 3. & Skor terrendah & $\mathbf{2 6}$ & $\mathbf{2 6}$ \\
\hline 4. & Rerata & $\mathbf{4 7 , 2 6}$ & $\mathbf{4 9 , 2 9}$ \\
\hline 5. & Range & 35 & 35 \\
\hline 6. & Modus & $\mathbf{5 3}$ & $\mathbf{5 0}$ \\
\hline 7. & Median & 48 & 50 \\
\hline 8 & Varians & 51,29 & 35,16 \\
\hline 9. & Stand. Deviasi & 7,16 & 5,92 \\
\hline 10. & N & 123 & 141 \\
\hline
\end{tabular}

Tabel di atas menjelaskan beberapa hal yang menarik tentang tes pengetahuan pedagogik guru. Dengan pendekatan komparatif (membandingkan) guru S2 dan S1, terlihat bahwa: skor tertinggi (61) dan skor terrendah (26) adalah sama. Sementara untuk nilai yang frekwensinya lebih banyak adalah lebih tinggi pada S1 (53) dibandingkan S2 (50). Sementara, nilai rata-ratanya S2 lebih tinggi $(49,29)$ dibandingkan dengan S1 $(47,26)$.

\section{Kemampuan Guru membuat Peren- canaan Pembelajaran}

Instrumen selanjutnya yang digunakan untuk menilai kualitas guru adalah menggunakan dokumen administrasi pembelajaran yakni dokumenRencana ProgramPembelajaran (RPP).Untuk itu telah dilakukan penilaian RPP oleh pengawas baik kepada responden alumni beasiswa Strata 2 ataupun yang Strata 1 . 
Berdasarkan hasil pengolahan data, diperoleh skor deskriptif sebagai berikut:

Tabel-2:

Hasil Skor Kemampuan membuat perencanaan Pelajaran (RPP), guru alumni S1 dan alumni S2.

\begin{tabular}{|l|l|l|l|}
\hline No & Deskripsi & $\begin{array}{l}\text { Nilai Guru } \\
\text { S1 }\end{array}$ & Nilai Guru S2 \\
\hline 1. & Sum & 9103,75 & 11466,25 \\
\hline 2. & Skor tertinggi & $\mathbf{9 8 , 7 5}$ & $\mathbf{1 0 0}$ \\
\hline 3. & Skor terrendah & $\mathbf{2 5}$ & $\mathbf{4 8 , 7 5}$ \\
\hline 4. & Rerata & $\mathbf{8 0 , 5 6}$ & $\mathbf{8 3 , 0 8}$ \\
\hline 5. & Range & $\mathbf{7 3 , 7 5}$ & 51,25 \\
\hline 6. & Modus & $\mathbf{9 3 , 7 5}$ & $\mathbf{9 2 , 5}$ \\
\hline 7. & Median & 85 & 87,5 \\
\hline 8 & Var & 201,53 & 130,33 \\
\hline 9. & Stand Deviasi & 14,19 & 11,41 \\
\hline 10. & N & 113 & 138 \\
\hline
\end{tabular}

Dari tabel diatas terlihat beberapa hal yang menarik tentang penilaian dokumen Rencana Program Pembelajaran yang dibuat oleh guru madrasah dan guru PAI di sekolah umum. Jika dibandingkan skor guru S2 dan S1, terlihat bahwa: skor tertinggi S1 $(98,75)$ lebih rendah dari pada S2 (100); dan skor terendah S1 lebih rendah (25) dari pada S2 $(48,75)$. Sementara untuk nilai yang frekwensinya lebih tinggi (modus) adalah pada S1 $(93,75)$ lebih tinggi dibandingkan S2 $(92,5)$. Sementara, nilai rataratanya S1 lebih rendah $(80,56)$ dibandingkan dengan S2 $(83,08)$.

\section{Penilaian Kepala Sekolah terhadap Kinerja Guru}

Instrumen selanjutnya yang digunakan untuk menilai kulitas guru adalah penilaian pimpinan terhadap kinerjanya. Ini dilakukian oleh Kepala sekolah/madrasah. Artinya, para guru yang menjadi sampel atau responden penelitian, kinerjanya dinilai oleh Kepala sekolahnya/madrasah. Berdasarkan hasil pengolahan data, diperoleh skor deskriptif sebagai berikut:
Tabel-3:

Skor Penilaian Kepala Sekolah terhadap kinerja guru alumni S1 dan alumni S2.

\begin{tabular}{|l|l|l|l|}
\hline No & Deskripsi & Nilai S1 & Nilai S2 \\
\hline 1. & Jumlah & 8809 & 11835 \\
\hline 2. & Skor tertinggi & 100 & 100 \\
\hline 3. & Skor terrendah & 50 & 66 \\
\hline 4. & Rerata & 81,56 & 84,53 \\
\hline 5. & Range & 50 & 34 \\
\hline 6. & Modus & 79 & 85 \\
\hline 7. & Median & 80 & 85 \\
\hline 8. & Var & 61,70 & 54 \\
\hline 9. & Standard Deviasi & 7,85 & 7,34 \\
\hline 10. & N & 108 & 140 \\
\hline
\end{tabular}

Dari tabel di atas terlihat beberapa hal yang menarik tentang penilaian kepala sekolah/madrasah terhadap kinerja guru madrasah dan guru PAI di sekolah umum. Jika dibandingkan skor guru S2 dan S1, terlihat bahwa: skor tertinggi S1 (100) sama dengan skor S2 (100); dan skor terendah S1 (50) lebih rendah dari pada S2 (66). Sementara untuk nilai yang frekwensinya lebih tinggi (modus) adalah pada S1 (79) lebih rendah dibandingkan S2 (85). Sementara, nilai rata-ratanya S1 $(81,56)$ lebih rendah dibandingkan dengan S2 $(84,53)$.

\section{Penilaian Siswa terhadap Kinerja Guru}

Selain penilaian pimpinan sekolah/ madrasah. Para siswa juga diminta untuk memberikan penilaian terhadap aspek-aspek pedagogik yang berkitan dengan hubungan siswa dan guru. Setiap satu sampel (satu orang guru) dinilai oleh dua responden (dua orang siswa) yang dipilih berdasarkan prestasi tertinggi dan terrendah di kelas yang diajar oleh guru yang menjadi sampel penelitian. Rerata penilaian dua orang siswa tersebut, menjadi skor untuk seorang guru. Berdasarkan hasil pengolahan data, diperoleh skor deskriptif sebagai berikut: 
Tabel-4:

Skor Penilaian Siswa terhadap Kinerja Guru alumni S1 dan alumni S2.

\begin{tabular}{|l|l|l|l|}
\hline No & Deskripsi & Nilai S1 & Nilai S2 \\
\hline 1. & Jumlah & 12124,47 & 15081,76 \\
\hline 2. & Skor tertinggi & $\mathbf{1 7 1}$ & $\mathbf{1 8 5}$ \\
\hline 3. & Skor terrendah & $\mathbf{7 5 , 5}$ & $\mathbf{7 7 , 5}$ \\
\hline 4. & Rerata & 100,20 & 106,20 \\
\hline 5. & Range & 95,5 & 107.5 \\
\hline 6. & Modus & $\mathbf{9 4 , 5}$ & 105,5 \\
\hline 7. & Median & 98,5 & 101,75 \\
\hline 8. & Var & 241,66 & 381,70 \\
\hline 9. & Standard Deviasi & 15,54 & 19,53 \\
\hline 10. & Count. & 121 & 142 \\
\hline
\end{tabular}

Dari tabel di atas terlihat beberapa hal yang menarik tentang penilaian siswa terhadap kinerja guru madrasah dan guru PAI di sekolah umum. Jika dibandingkan skor guru S2 dan S1, terlihat bahwa: skor tertinggi S1 (171) lebih rendah dari skor S2 (185); dan skor terendah S1 $(75,5)$ lebih rendah dari pada S2 $(77,5)$. Sementara untuk nilai yang frekwensinya lebih tinggi (modus) adalah pada S1 $(94,5)$ lebih rendah dibandingkan S2 $(105,5)$. Sementara, nilai rata-ratanya S1 $(100,20)$ lebih rendah dibandingkan dengan S2 $(106,20)$.

\section{Inovasi dan Kreativitas Guru}

Secara keseluruhan, data ini mendeskripsikan produktivitas guru madrasah dan guru agama Islam alumni S2 dalam melakukan inovasi pembelajaran dan karya tulis ilmiah. Beberapa indikator yang menjadi aspek penilaian adalah kemampuan membuat penelitian tindakan kelas, menulis buku, dan melakukan publikasi karya tulis di media dan jurnal. Berdasarkan data yang terkumpul diperoleh hasil sebagai berikut:
Tabel-5:

Kreativitas Guru S2

\begin{tabular}{|l|l|l|l|l|l|l|}
\hline \multirow{2}{*}{ No } & \multirow{2}{*}{ Jenis karya tulis } & \multicolumn{2}{|l|}{ Ada } & \multicolumn{2}{l|}{ T.A } & \multirow{2}{*}{ Ket. } \\
\cline { 3 - 7 } & & $\Sigma$ & $\%$ & $\Sigma$ & $\%$ & \\
\hline 1 & Melakukian PTK & 41 & 26,11 & 116 & 73,89 & $\mathrm{~N}=157$ \\
\hline 2 & Menerbitkan buku & 38 & 24,20 & 119 & 75,80 & \\
\hline 3 & $\begin{array}{l}\text { Publikasi jurnal } \\
\text { dan Media }\end{array}$ & 27 & 17,20 & 130 & 82,80 & \\
\hline
\end{tabular}

Tabel tersebut mengambarkan bahwa terdapat $26,11 \%$ atau 41 orang guru yang telah melakkan penelitian tindakan kelas (PTK) dari 157 total responden; Terdapat $24,20 \%$, atau 38 orang guru yang telah menulis buku dari 157 total responden; Terdapat 17\%, atau 27 orang guru dari 157 total responden, yang telah mempublikasikan gagasan atau pikirannya melalui tulisan di Jurnal atau media massa umum.

Sementara guru alumni S1 dengan indikator yang sama, yang memiliki kreativitas dan produktivitas karya ilmiah adalah sebagai berikut:

Tabel-6:

Kreativitas Guru S1

\begin{tabular}{|c|l|l|l|l|l|l|}
\hline \multirow{2}{*}{ No } & \multirow{2}{*}{ Jenis karya tulis } & \multicolumn{2}{|l|}{ Ada } & \multicolumn{2}{|c|}{ T.A } & \multirow{2}{*}{ Ket. } \\
\cline { 3 - 6 } & & $\Sigma$ & $\%$ & $\Sigma$ & $\%$ & \\
\hline 1 & Melakukian PTK & 9 & 6,47 & 130 & 93,53 & N = 139 \\
\hline 2 & Menerbitkan buku & 5 & 3,59 & 134 & 96,41 & \\
\hline 3 & $\begin{array}{l}\text { Publikasi jurnal dan } \\
\text { Media }\end{array}$ & 1 & 0,71 & 138 & 99,29 & \\
\hline
\end{tabular}

Tabel di atas menjelaskan bahwa terdapat $6,47 \%$, atau 9 orang guru dari 139 total sampel yang telah melakukan penelitian tindakan kelas (PTK); Terdapat 3,59\%, atau 5 orang guru dari 139 total sampel yang telah menulis buku; dan sebanyak $0,71 \%, 1$ orang guru dari 139 total sampel yang telah berhasil mempublikasikan pikirannya melalui tulisan di Jurnal atau media massa publik.

Secara rinci produktivitas guru dalam melakukan inovasi pembelajaran dan karya tulis ilmiah disajikan dalam tabel beriut ini: 
Tabel-7:

Perbandingan Kreativitas Guru S2 dan S1

\begin{tabular}{|l|l|l|l|l|l|l|}
\hline \multirow{2}{*}{ NO } & \multirow{2}{*}{ Jenis karya tulis } & \multicolumn{4}{|l|}{ S1 } & \multicolumn{3}{l|}{ S2 } & \multirow{2}{*}{ Ket. } \\
\cline { 3 - 7 } & & $\Sigma$ & $\%$ & $\Sigma$ & $\%$ & \\
\hline 1 & Melakukian PTK & 9 & 6,47 & 41 & 26,11 & \\
\hline 2 & Menerbitkan buku & 5 & 3,59 & 38 & 24,20 & \\
\hline 3 & $\begin{array}{l}\text { Publikasi jurnal dan } \\
\text { Media }\end{array}$ & 1 & 0,71 & 27 & 17,20 & \\
\hline
\end{tabular}

Berdasarkan tabel tersebut, terlihat bahwa kreativitas dan produktivitas guru alumni S2 baik dalam melakukan penelitian tindakan kelas (PTK), menerbitkan buku maupun dalam mempublikasikan tulisan di jurnal dan media, lebih tinggi dibandingkan dengan guru alumni s1.

\section{Pengujian Hipotesis}

Pada bagian ini akan dilakukan pengujian hipotesis melalui uji beda antara guru alumni S2 dan S1. Adapun pernyataan hipotesis tersebut adalah:

- Ho: Tidak ada perbedaan antara mutu guru PAI dan madrasah yang berpredikat strata 2 dan strata 1.

- H1: Ada perbedaan antara mutu guru PAI dan madrasah yang berpredikat strata 2 dan strata 1.

Uji hipotesis ini dilakukan untuk mengetahui signifikansi perbedaan mutu gur alumni strata 2 dan guru alumni stragta 1, melalui kemampuan pedagogiknya, kemampuan menyusun RPP, dan kinerjanya berdasarkan penilaian penilaian kepala sekolah dan penilaian siswa. Jika perbedaan mutu guru pendidikan agama Islam di SMU dan Madrasah signifikan, berarti terdapat pengaruh yang signifikant atas qualifikasi guru PAI/ madrasah terhadap mutu guru agama di sekolah dan madrasah. Proses pengujian dilakukan dengan menggunakan software PASW18. Proses pengujian dilakukan dengan menggunakan prosedur "Independent Sample
t-Test". Pengambilkan keputusan ditentukan sebesar 0,05 atau $95 \%$ confidence interval of the difference. Jika nilai Sig < 0,05, maka HO ditolak; sebaliknya jikan nilai Sig $>0,05$, maka Ho diterima.

Hipotesis pertama yang akan diuji adalah: "Tidak terdapat perbedaan antara hasil tes pedagogik guru alumni S2 dengan guru S1", dengan hipotesis alternatif, "Terdapat perbedaan antara hasil tes pedagogik guru alumni S2 dengan guru S1". Berdasarkan perhitungan statistik "Independent sample t-Test, dengan menggunakan sofrware SPSS diperoleh hasil 0,015. Ini berarti lebih kecil dari 0,05 , yang berarti HO ditolak. Dengan demikian hipotesis yang menyatakan tidak terdapat perbedaan antara hasil tes pedagogik guru alumni S2 dengan guru S1, ditolak. Artinya, terdapat perbedaan antara kemampuan pedagogik guru S2 dengan guru S1. Secara rinci hasil perhitungan SPSS ditampilkan di bawah ini.

Tabel-9:

Hasil analisis SPSS tentang Kemampuan Pedagogik guru

Independent Samples Test

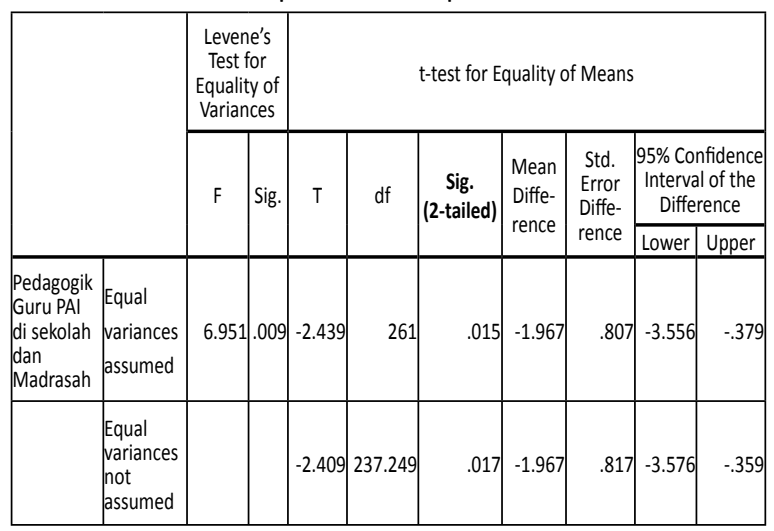

Hipotesis kedua yang akan diuji adalah: "Tidak terdapat perbedaan antara hasil penilaian RPP guru alumni S2 dengan guru S1", dengan hipotesis alternatif, "Terdapat perbedaan antara hasil penilaian RPP guru alumni S2 dengan guru S1". Berdasarkan perhitungan statistik "Independent sample t-Test, dengan menggunakan alat SPSS 
diperoleh hasil 0,186. Ini berarti lebih besar dari 0,05 , yang berarti Ho diterima. Dengan demikian hipotesis yang menyatakan tidak terdapat perbedaan antara hasil penilaian RPP guru alumni S2 dengan guru S1, diterima. Artinya, tidak terdapat perbedaan antara kemampuan kemampuan membuat perencanaan pembelajaran antara guru S2 dengan guru S1. Secara rinci hasil perhitungan SPSS ditampilkan dalam Tabel-10.

Tabel-10:

Hasil analisis Kemampuan Merencanakan Pelajaran Guru

Independent Samples Test

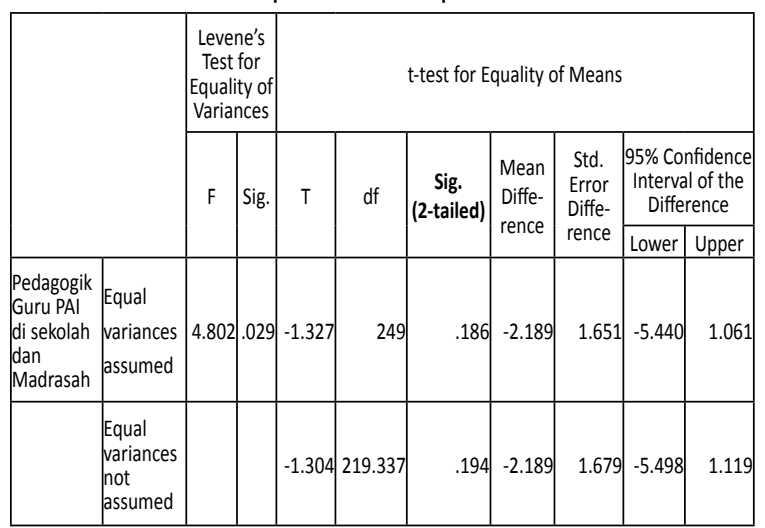

Hipotesis ketiga yang akan diuji adalah: "Tidak terdapat perbedaan penilaian Kepala Sekolah/Madrasah terhadap kinerja guru alumni S2 dengan guru alumni S1", dengan hipotesis alternatif, "Terdapat perbedaan antara penilaian Kepala Sekolah/Madrasah terhadap guru alumni S2 dengan guru alumni s1". Berdasarkan perhitungan statistik "Independent sample t-Test, dengan menggunakan alat SPSS diperoleh hasil 0,002 . Ini berarti lebih kecil dari 0,05 , yang berarti Ho ditolak. Dengan demikian hipotesis yang menyatakan tidak terdapat perbedaan penilaian Kepala Sekolah/Madrasah terhadap kinerja guru alumni S2 dengan guru alumni S1, ditolak. Artinya, kinerja guru madrasah dan guru pendidikan agama Islam yang berkualifikasi S2 berbeda dengan guru yang S1 berdasarkan penilaian Kepala Sekolah atau Kepala Madrasah. Secara rinci hasil perhitungan SPSS ditampilkan dalam Tabel-11.

Tabel-11:

Hasil analisis Penilaian Kepala Sekolah terhadap Kinerja Guru

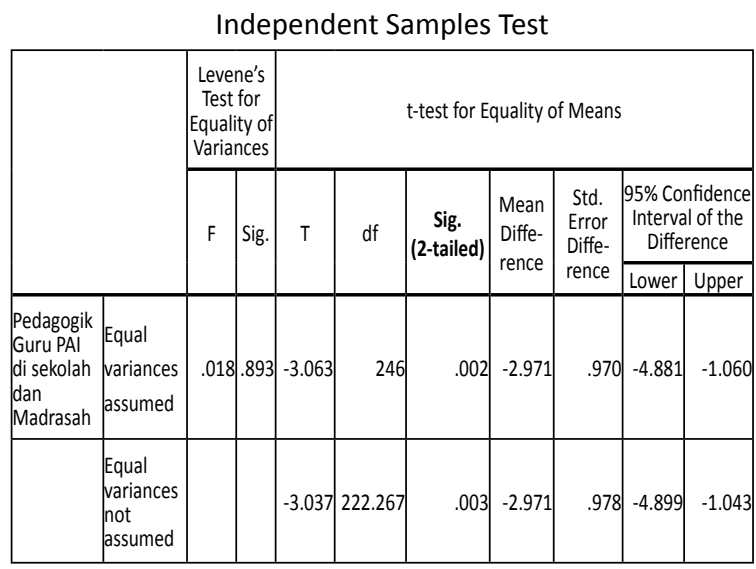

Hipotesis keempat yang akan diuji adalah: "Tidak terdapat perbedaan penilaian siswa kepada kinerja guru alumni S2 dengan guru alumni S1", dengan hipotesis alternatif, "Terdapat perbedaan antara penilaian siswa terhadap guru alumni S2 dengan guru alumni S1". Berdasarkan perhitungan statistik "Independent sample t-Test, dengan menggunakan alat SPSS diperoleh hasil 0,017. Ini berarti lebih kecil dari 0,05, yang berarti Ho ditolak. Dengan demikian hipotesis yang menyatakan tidak terdapat perbedaan penilaian siswa kepada kinerja guru alumni S2 dengan guru alumni s1, ditolak. Artinya, di mata para siswanya, kinerja guru madrasah dan guru pendidikan agama Islam yang berkualifikasi S2 berbeda dengan guru yang S1. Secara rinci hasil perhitungan SPSS ditampilkan dalam Tabel-12. 
Tabel-12:

Hasil analisis Penilaian Siswa terhadap Kinerja Guru PAI

Independent Samples Test

\begin{tabular}{|c|c|c|c|c|c|c|c|c|c|c|}
\hline & \multicolumn{2}{|c|}{$\begin{array}{l}\text { Levene's } \\
\text { Test for } \\
\text { Equality of } \\
\text { Variances }\end{array}$} & \multicolumn{7}{|c|}{ t-test for Equality of Means } \\
\hline & & \multirow[t]{2}{*}{$\mathrm{F}$} & \multirow[t]{2}{*}{ Sig. } & \multirow[t]{2}{*}{ T } & \multirow[t]{2}{*}{ df } & \multirow[t]{2}{*}{$\mid$\begin{tabular}{c|} 
Sig. \\
(2-tailed)
\end{tabular}} & \multirow{2}{*}{$\begin{array}{l}\text { Mean } \\
\text { Diffe- } \\
\text { rence }\end{array}$} & \multirow{2}{*}{$\begin{array}{l}\text { Std. } \\
\text { Error } \\
\text { Diffe- } \\
\text { rence }\end{array}$} & \multicolumn{2}{|c|}{$\begin{array}{l}95 \% \text { Confidence } \\
\text { Interval of the } \\
\text { Difference }\end{array}$} \\
\hline & & & & & & & & & Lower & Upper \\
\hline $\begin{array}{l}\text { Pedagogik } \\
\text { Guru PAI } \\
\text { di sekolah } \\
\text { dan } \\
\text { Madrasah }\end{array}$ & $\begin{array}{l}\text { Equal } \\
\text { variances } \\
\text { assumed }\end{array}$ & 2.191 & 1.140 & -2.395 & 265 & .017 & $|-5.101|$ & 2.130 & $|-9.295|$ & -.907 \\
\hline & $\begin{array}{l}\text { Equal } \\
\text { varaiances } \\
\text { not } \\
\text { assumed }\end{array}$ & & & -2.434 & 264.993 & .016 & -5.101 & 2.096 & -9.228 & -9.974 \\
\hline
\end{tabular}

\section{PENUTUP}

Berdasarkan uraian deskriptif dan pembahasan tersebut di atas, maka dapat disimpulkan beberapa hal penting, terkait dengan pengaruh kualifikasi guru terhadap mutu guru agama di sekolah dan madrasah, sebagai berikut: 1). Secara umum, terdapat pengaruh kualifikasi guru terhadap peningkatan pengetahuan pedagogik guru. Hal ini terlihat dari tingginya skor rerata hasil tes pengetahuan guru S2 dibanding guru S1. Melalui uji statistik imperensial di peroleh nilai beda yang signifikan antara pengetahuan pedagogik guru alumni S2 dan guru alumni S1. 2). Secara umum, tidak terdapat pengaruh kualifikasi guru terhadap peningkatan keterampilan membuat perencanaan pembelajaran. Hal ini berdasarkan uji statistik, dimana secara imperensial diperoleh nilai beda yang tidak signifikan antara skor keterampilan membuat perencanaan pembelajaran guru S1 dan guru S2. 3). Secara umum, terdapat pengaruh kualifikasi guru terhadap peningkatan aktifitas mengajar guru. Hal ini secara sederhana terlihat dari tingginya skor rerata penilaian Kepala Sekolah dan penilaian siswa kepada guru alumni S2 dibandingkan guru alumni S1. Melalui uji Statistik juga diketahui adanya perbedaan nilai yang siginfikan antara S2 dan S1. 4). Secara umum, terdapat pengaruh kualifikasi guru terhadap peningkatan kreatifitas dan inovasi guru untuk meningkatkan mutu pendidikan. Hal ini terlihat dari tingginya perbedaan angka presentase aktifitas melakukan publikasi dan penelitian oleh guru alumni pendidikan S2. 5). Meskipun secara inferensial, terdapat pengaruh kualifikasi guru terhadap mutu guru, tetapi secara kualitatif hal tersebut tidak bersifat absolut. Karena beberapa nilai statistik yang lain menunjukkan indikator bahwa guru Strata 1 juga memiliki kompetensi yang setara bahkan lebih baik dari guru alumni S2 (kecuali pada aspek inovasi dan kreativitasnya).

Berdasarkan kesimpulan tersebut di atas, maka penelitian ini memberikan rekomendasi, sebagai berikut: 1). Pemerintah pada umumnya, dan stake holder pendidikan khususnya, perlu memberikan motivasi dan kesempatan kepada para guru yang berminat untuk melanjutkan pendidikan ke jenjang Strata 2 dengan memperhatikan kesesuaian disiplin ilmu yang diajarkan. 2). Penyelenggaraan beasiswa strata dua yang selama ini sudah dilaksanakan agar diteruskan dengan memperbaiki sistem penyelenggaraannya, sehingga dapat memberikan kesempatan yang fair kepada seluruh guru yang berminat. Sistem rekruitment dan seleksi terbuka dan bersaing bagi calon peserta akan menghasilkan alumni guru yang berkualitas. 3). Pemerintah juga melalui pusat pendidikan dan pelatihan pegawai (Pusdiklat, Balai Diklat, LPMP) secara bersinergi memberikan layanan penguatan kompetensi dan profesionalisme guru. Data tersebut di atas menunjukkan bahwa guru alumni S2 bukan merupakan jaminan untuk mengajar secara maksimal, terdapat beberapa orang guru (dalam sampel peneltian ini) yang kualitasnya dibawah guru alumni S1. Dan juga tidak semua guru alumni memiliki output karya tulis ilmiah sebagai salah satu indikator guru yang kreatif dan inovatif. Pembinaan kualitas guru melalui aktivitas kediklatan menjadi penting. Pusat dan Balai Pendidikan dan Pelatihan dapat menjadi wadah pemelihara (maintaining) semangat profesionalisme dan mutu para guru. 


\section{DAFTAR PUSTAKA}

Ali, Muhammad (2009): Pendidikan Untuk Pembangunan Nasional. Bandung, Imperial Bhakti Utama.

Depdiknas (2001): Kamus Besar Bahasa Indonesia. Jakarta, Balai Pustaka.

Djamarah, Syaiful Bahri (1994): Prestasi Belajar Siswa dan Kompetensi Guru. Surabaya, Usaha Nasional.

Djamarah, Syaiful Bahri (2000): Guru dan Anak Didik dalam Interaksi Edukatif. Jakarta, PT Rineka Cipta.

Harold, Kerzner (2009): Project Management: A System Approach To Planning, Schedulling And Controlling. New Jersey, Jhon Willey\& Sons, Inc Hoboken.

Hoy. Charles, Colin Bayne-Jardin, dan Margaret Wood (2000): Improving Quality in Education. London, Falmer Press.

http://en.wikipedia.org/wiki/Teaching_ qualification.

http://www.businessdictionary.com/ definition/qualification.html.

http://www.thefreedictionary.com/ qualification.

Husaini, Usman (2006): Manajemen Teori, Praktek Dan Riset Pendidika. Jakarta, Bumi Aksara.

Juran, J.M. (1989): Juran on Leadership for Quality, An Executive Handbook. New York, Macmillan Inc.

Peraturan Pemerintah No. 19 tahun 2005, tentang Standard Nasional Pendidikan.

Sallis. Edward (2008): Total Quality Management in Education: Manajemen mutu pendidikan. Yogyakarta, IRCiSod.

Suderadjat, Hari (2005): Manajemen Peningkatan Mutu Berbasis Sekolah; Peningkatan mutu pendidikan Melalui Implementasi KBK. Bandung, Cipta Lekas Garafika.

Suryosubroto. B. (2002): Proses Belajar Mengajar di Sekolah. Jakarta, P.T. Rineka Cipta.

Syah, Muhibbin (1997): Psikologi Pendidikan dengan Pendekatan Baru, Bandung, Remaja Rosdakarya.

Undang-Undang No. 14 Tahun 2005 tentang Guru dan Dosen.
Undang-Undang No. 20 Tahun 2003 tentang Sistem Pendidikan Nasional.

Yuhetty, Harina (2006): Laporan Kajian 'Prakarsa Sekolah dalam Meningkatkan Mutu Proses Pendidikan (Studi Kasus pada SMA/MA Terpilih). Jakarta, Depdiknas. 